\title{
Minorities in Pakistan: Role of Pakistani Private TV Channels in Highlighting Minorities' Rights
}

\author{
Amber Mubeen, University of the Punjab, Pakistan \\ Rabia Qusien, University of Lahore, Pakistan
}

\begin{abstract}
Religious minorities in Pakistan "are believed to be much more than the estimated figures of 5 percent of Pakistan's 160 million population". Minorities were enjoying good relationship with Muslim community but since few years some violent incidents resulting in destruction of the life and property were reported by media. Being a forth state of a society, media is expected to present all marginalized groups within it and to give an account of all incidents in a responsible way. This study finds out the role of Pakistani TV Channels to highlight minorities' rights in Pakistan and to create harmony among all groups residing in the country. With mix methodology of qualitative and quantitative, data $(\mathrm{N}=456)$ was taken from students of five different universities of Lahore to know their perspective about the role of the Private Television channels to highlight minorities' rights and their contribution in presenting the stories related to minorities. Data analysis shows that respondents find private TV channels quite vocal to give them awareness about minority rights and to share the incidents in a neutral way but respondents do not find private TV channels active in creating harmony among different minorities 'groups.
\end{abstract}

Keywords: Minority rights, Private TV channels, TV coverage, Muslim Christian relations, social responsible media, 


\section{Introduction}

Pakistan is a Muslim state with an amalgamation of different cultures, languages, ethnicities, religions and sects. Different minorities groups including Christians, Hindu, Sikh, Parsi, Ahmadiya, Buddhist, and others are also living here since 1947. According to world directory of Minorities and indigenous peoples in Pakistan "Religious minorities include Christians (1.59\%), Ahmaddiyas (0.22 \%), Hindus (1.6\%), Shi'as, Isma'ilis, Bohras and Parsis" make a considerable percentage (Demographic indicators-1998 Census, 2015). According to one report about minority it is noted that population of Ahmadi in Pakistan is specifically contested and statistics show that they are less than half of million or they are 600,000. Many of this community are located in Rabwah and they are mostly well educated (Dilawr et al., 2014).

According to oxford dictionary definition minority is "A small group of people within a community or country, differing from the main population in race, religion, language, or political persuasion" (Oxford Dictionary). Similarly another definition given by University of Colorado states that "Minorities may be defined on religious, racial, ethnic, gender or political differences which arise among all groups". Minorities find democratic process troublesome because majority can threaten them by using their power (Protection of Minority Rights, 2015). One of definition given to United nation by their special reporter on minority suggest that "A group numerically inferior to the rest of the population of a State, in a nondominant position, whose members - being nationals of the State-possess ethnic, religious or linguistic characteristics differing from those of the rest of the population and show, if only implicitly, a sense of solidarity, directed towards preserving their culture, traditions, religion or language". Although there is no consensus on definition of minority but different scholars and sources used to define it differently (United Nation Human rights office of the high commissioner, 2010).

For a democratic process of any country, all citizens need to acknowledge their responsibilities to drive country on development routes. Minorities are playing an effective role in different walks of life as they are working in different professions like medical, business, civil services, academics and in media to contribute their services for the prosperity of the country. Minorities become more satisfied and positive when their role is considered significant by the majority. 
In Pakistan, Christians owe a big ratio of population. Christians' community has played a friendly role towards Muslims and they have supported the stance of Muslims in Pakistan Movement. "The Christians supported Mr. Jinnah and All India Muslim League when there was substantial opposition in and outside the country". (Munir-ul-Anjum \& Tariq, 2012).

Since its birth, Pakistan knows the importance of minorities which can be determined from the white part of its national flag which is devoted to minorities groups by conceding their existence.

Respect for minorities' rights is reckoned as an icon for democracy which is measured by respecting the declarations of human rights. Kozar (2005) adds that according to the article 2 which was promulgated in 1992, "persons who belong to any kind of minority have the right to enjoy their own culture, to practice their religion, to use their language, in private and in public, freely and without any kind of discrimination". Other than it "Christianity is the second biggest religion in the country with 1.59 percent (roughly 2.5 million) followers (Shahab, 2010). Therefore, relations between Muslims and Christians are seen more fluctuating as compare to other minority groups. That's why this study will also focus more on Muslims Christian relations.

In Pakistan, all minorities are living together without any major variances but in some previous years, some disputes between Muslim and Christian community occurred like blasphemy cases, burning Christian communities and hatred aroused between both sects.

Such disputes give birth to more blazing and situations when something happens related to religion. Blind followers usually don't bother to call the police and they try to handle the situation by themselves which end up in loss of property or death of accused person.

Under blasphemy cases, relations of Muslims Christian became more scorching when "In 2010, a Christian woman Aasiya Bibi was sentenced to death in a blasphemy case" (Jalil, 2015). 
Shahab (2010) says that Aasia is "believed to be the first woman sentenced to death under Pakistan's infamous laws, therefore this issue has become international and even the Pope Benedict XVI has demanded justice for the woman".

In 2013, enraged mob of More than 3,000 Muslims raged in Joseph colony, Badami Bagh Lahore, and burnt around 100 Christian houses as they were in search of an allegedly blasphemer Savan. Savan Masih was accused of having conversation with a Muslim friend and he was convicted of insulting Holy Prophet (AFP, 2014).

"In November 2014, a Christian couple who worked at a brick kiln in Kot Radha Kishan (Kasur), was killed brutally by being burnt to death in the kiln fire, ostensibly over blasphemy, but the case still lies in court and the reason is still not confirmed". (Jalil, 2015). An enraged Muslim mob beat a Christian couple to death near Lahore and burnt their bodies in the brick kiln where they worked. This couple was burnt when people charged them of blasphemy and they were alleged of damaging the Holy Quran. After being reported by electronic media, Chief Minister Punjab, Shahbaz Sharif, took notice and formed a five member committee to inspect this matter. He also announced a compensation of 2 million rupees for the suffered families (The Express Tribune, 2014).

Another unpleasant incident was reported in 2015 in Youhanabad Lahore, which is known as the largest Christian Community in Lahore where two churches were attacked by two suicide bombers after being stopped by the security guards. In this incident, fourteen people were dead and more than 70 people were injured. These attacks sparked the resentment and more than 4,000 Christians came on the roads and attacked City Metro bus station, armed with clubs. While protesting, two Muslim young men were beaten to death while crossing the road by aggressive mob and whom they suspected of being associates of the attackers. (Gabol et al., 2015)

In August 2015, a vicious crowd attacked the Christians in Sanda Lahore where they found an alleged man Hamyun Masih for burning the verses of Holy Quran. People ransacked the Churches and attacked the locals. After that Humayun Mashih was taken in to police custody. (Daily Times, 2015). 
Likewise, Ahmadi community is also subjected to discriminatory behavior i.e. "in December 2012 suspected militants desecrated 120 Ahmadi gravestones in Lahore, while in March 2013 an Ahmadi family in Kasur was brutally attacked in their home by local clerics after they allegedly refused to convert to Sunni Islam”. Another incident in 2013 reported that an Ahmadi family was expelled from their business premises because they run a magazine "The Weekly Lahore". Similarly, in July 2013 their worship place in Fatehpur, Gujrat was also taken away by a group of Sunnis (Dilawr et al., 2014).

Media plays a significant role to bring details of such incidents to the people and audience expect from media to give them an account of the incidents in a more rigorous way. After PTV, a state owned Channel, advent of new private TV channels in Pakistan since 2000 has created an informatory wave and Pakistanis have experienced a more exciting and liberal side of the private media. Since that time, people used to take Media as a primary tool to get news of the surroundings. This change made people more dependent on the media to get stories. Birth of Social networking sites gave another challenge to private TV channels and they had to be more vocal by providing the both sides of the story by showing leniency regarding their organizational policy at times. It is not unusual on social media networking sites to discuss the different stories but also the role of the different TV channels. People are more vigilant now-a-days and they want to know the both sides of the coin as they have the platform of social media where they can interact with others to get the insight of the story. By keeping this factor in mind, TV channels became strained to modify their programs' content.

Importance of the media to educate a society is taken very noteworthy for every society and same lies with Pakistan. Media can play a role of a mediator by producing constructive programs to bring both communities together. Similarly there is a dire need to address the issue of blasphemy and awareness about minorities' rights. Media can teach the lesson of tolerance and patience to all people by throwing the light on the importance of humanity and the constitution of Pakistan which grants identical rights to minorities. Similarly the purpose of creating harmony among all minorities groups can be fulfilled by media. Another important doctrine of "interfaith dialogues" can be fruitful for bridging the gap among all minorities. 
This study will analyze the role of private Pakistani TV channels for highlighting minorities' rights and to create harmony through their programs. Study will also determine that either media is fulfilling its responsibility to give awareness about different minorities rights and to present the story in a responsible way. Through stratified sampling method, a sample of 456 students is taken from five different universities of Lahore to know the perspective of students regarding the role of Pakistani private channels. This study will deploy mix methodology of quantitative and qualitative to get an insight of students' perspective. Survey method is deployed by distributing questionnaire to university students and interviews of 115 students were arranged for this study. Universities selected for this study include three public sector universities Punjab University and Lahore College for Women University, Kinnaird College University Lahore (A Christian University) and two private universities including Superior university and Forman Christian College (A Chartered University) which own a big strength of Christian students. Data was collected at the end of 2014 and in the beginning of 2015 which was a soaring time of Muslims Christian conflict.

\section{Review of Literature}

Mass media is sweeping in all walks of life with the passage of time and it is considered helpful because it is catering the needs of individuals varying from political matters to entertainment. Katz, Haas and Gurevitch (1973) also stated that television is considered one of important medium which is gratifying both political and personal needs of users. In Pakistani society after the freedom of media numbers of channels are penetrating into the market and it is having a strong impact on the lives of individuals. Electronic media is actually helping people to change their lifestyle. It helps in creating popularly accepted ideas by leaving strong impact on the society (Ali, 2013).

Respect for diversity or multiculturalism is one of important mainstream debate in $21^{\text {st }}$ century. For example, Verkuyten maintained that "Diversity is considered desirable and necessary for the development of secure ethnic identities and positive self-feelings, but is also challenged for being inequitable and a threat to social cohesion". There is no specific approach for improving and supporting the diversity but it can be examined that what are important factors which affect multiculturalism and diversity (2006, p. 148). 
Media is a central pillar which can help in promotion of minority rights in any society. Role of media must be responsible enough that they can create and maintain harmony among different ethnic and religious groups. When they are devising propaganda strategies rights, identities, religious beliefs and norms of minorities must be protected. News media, television, film etc can play a vital role in this regard (Hagendoorn \& Nekuee, 1999). Greenberg also noted that minority groups are underrepresented in media both as subject of news and news presenters. It is also concluded revealed that news stories related to minorities are used to have negative attributes. Such conflicts augment with a ferocious pace can be dreadful, thus preventing measures must always be taken to reduce these conflicts.

Even in today world mass media in many countries is under representing the minorities. For instance, Gerbner and Signoriel found that both minorities and women are underrepresented entities of the society. They found that if they are depicted in dramas etc they are shown vulnerable characters who are subjected to violence frequently (1979). Similarly, Mastro and Robinson (2000) concluded that literature on media's depiction of minorities reveals that media is focusing on stereotypical and negative roles of minorities. Their analysis of media content reveals that law enforcement institutes have harsher attitude towards the minority perpetrators. This stereotypical image of the minorities is used to affect the perception of users in longer terms.

When depiction of African Americans was examined in prime-time television series in 1987 than it was found that over the period of time the depiction and participation of African Americans has improved over the period of time. Intervention on the level of establishment has helped in more portrayal of African American comical settings (Stroman, Merritt, \& Matabane, 1989). In current scenario in order to make money most of the media outlets are not in favor of broadcasting public service messages. For instance, Watson found that preservation of Irish is not supported ideologically because these ideas are not supported by current environment. Competition among different channels is hindering the channels from broadcasting public service content. He concluded that there is need for new separate channel for promoting minority rights and some interventions will help in making situation better (1996). 
Henrard in his book written in South African context noted that some interventions in the field of media and culture can help in putting strong emphasis on the importance of diversity. The depiction of diversity of people will help in addressing the issue of their identity (2002, p.221). Likewise, another study states that some scholars assume that when communication system i.e. media etc along with democracy will be consolidated it will help in solving the issues of minorities and their nationalism. On contrary, democratic, globalized and developed countries supports the ethnic diversity and minority identities (Kymlicka, 2002, pp. 18-19).

Sadruddin, (2012) tried to investigate the role of media, civil society and NGOs in advocating and supporting pluralism. "Contributions of these organizations in stressing human values such as liberty, equality, brotherhood, religious bonding, etc., beside its role in the social and economic development of Pakistan" was part of research process. He concluded that media, civil society and NGOs all are developing sectors of country and they are playing a significant promoting and sustaining a diverse and pluralist society.

\section{Research Questions}

- Are Pakistani TV channels highlighting minorities' issues through their content?

- Are Pakistani TV channels promoting minorities' rights?

- Do Pakistani channels present an objective view of minorities' issues and concerns?

\section{Hypothesis}

- H1: Pakistani TV channels are highlighting minority issues through their content.

- H2: Pakistani private TV channels have been successful in creating awareness of minorities' issues/rights.

- H3: Pakistani channels are significantly promoting minority rights.

- H4: Pakistani TV channels are fair in their coverage about minority rights.

\section{Theoretical Framework}

This study will use uses and gratification theory as its theoretical base. 


\section{Uses and Gratification Theory}

This theory aims to highlight the different use made by different people. "Uses and gratifications theory attempts to explain the uses and functions of the media for individuals, groups, and society in general. Being active audience, people can identify their required medium to seek information. "The audience is provided with an opportunity to make a wide range of media selections. Such choices could be between one newspaper and another" (Emenyeonu, 1995).

Uses and gratification was presented by Katz, "when he came up with the notion that people use the media to their benefit" (Spring, 2002). This theory was considered contemporary which it declared audience as the active one. Before that people were assumed as passive. But Katz and his colleagues put emphasis on audience and claimed that "they actively seek out specific media and content to achieve certain results or gratifications that satisfy their personal needs" (Spring, 2002).

This perspective emerged in the early 1970's as Katz and his two colleagues, Jay Blumler and Michael Gurevitch continued to expand the idea (Spring, 2002).

This theory addresses the concern why people use particular media rather than on content. In contrast to previous concern of the 'media effects' addressing that 'what media do to people' this theory is more concerned with 'what people do with media. As shared by (Chandler, 1995) "watching TV helps to shape audience needs and expectations". Uses and gratification arose originally in the 1940s and underwent a revival in the 1970s and 1980s".

The study in hand uses the uses and gratification theory as a theoretical framework that why people use and watch TV and why they prefer to use TV to get the details of the story. What kind of need is fulfilled by Television set which tells the stories most of the times. And they come to know about any incident, do they prefer to watch TV for surveillance of the information or not? This study is about the role of Television, to highlight not only the minority issues but also to create harmony among different races living in Pakistan. Questions were asked regarding the content of TV to highlight and create harmony among all minorities. 


\section{Social Responsibility Theory}

Media being a forth state is always expected to be a watch dog of society which highlights all wrongdoing and positive practices of its citizen. Theory of social responsibility was introduced under the umbrella of normative theories. "Social responsibility theory is a modified version of free press theory, placing greater emphasis upon the accountability of the media to society".

According to Ravi (2012) "It is an extension of the libertarian philosophy in that the media recognize their responsibility to resolve conflict through discussion and to promote public opinion, consumer action, private rights, and important social interests".

Media has the capacity to form the attitude and opinion then the responsibility becomes a pivotal characteristic of the media raises more high that media should use its power "to ensure appropriate delivery of information to audiences; furthermore, if the media fails in carrying out this responsibility, it may be relevant to have a regulatory instance enforce it" (Middleton, 2009).

That's why expectations of people go beyond the imagination which they associate with media. People expect from media to show them the evil face of the society but to bring reforming discussion platforms as well which are criticizing government but educating people as well to guide them for the well-being of the country. It requires a powerful media yet a responsible tool wrapped by social responsibilities. Journalists have a duty to provide well-contextualized news in a comprehensive manner. They have a duty to provide a diverse forum of views and values. They have a duty to provide impartial analysis of different events except entertaining news.

This study uses the framework of social responsible media that are Pakistani TV channels are playing a responsible role while giving awareness about minority rights and are they unbiased while giving an account of the story. Being a mirror of society, media is expected to be careful to give an account of any piece of information and it should be extra vigilant to talk about minorities as they might feel to be isolated. This study will check that either the Pakistani private TV channels are behaving responsibly and are presenting an unbiased view over any news story related to minorities. Do the media behave in a balanced way to educate 
and inform the people about the different happenings of the minorities or it exaggerates the news items.

\section{Results}

\begin{tabular}{|c|c|c|c|c|c|c|}
\hline \multicolumn{7}{|l|}{ Descriptive Statistics } \\
\hline & $\mathrm{N}$ & Min & Max & Mean & $\begin{array}{l}\text { Std. } \\
\text { Deviation }\end{array}$ & Variance \\
\hline Do you watch TV & 456 & 1.00 & 3.00 & 1.5000 & .83600 & .699 \\
\hline Knowledge about minorities & 456 & 1.00 & 3.00 & 1.3421 & .71810 & .516 \\
\hline Knowledge about minorities rights & 456 & 1.00 & 3.00 & 1.9013 & .90973 & .828 \\
\hline Knowledge of FOE and religious security & 456 & 1.00 & 3.00 & 1.4605 & .79461 & .631 \\
\hline $\begin{array}{l}\text { Knowledge of issues between Muslims and } \\
\text { minorities }\end{array}$ & 456 & 1.00 & 3.00 & 1.5395 & .78627 & .618 \\
\hline $\begin{array}{l}\text { Knowledge of conflicts between Muslims and } \\
\text { minorities }\end{array}$ & 456 & 1.00 & 3.00 & 1.5526 & .77706 & .604 \\
\hline Knowledge of Blasphemy Law & 456 & 1.00 & 3.00 & 1.7368 & .67681 & .458 \\
\hline Knowledge of Burning Christians & 456 & 1.00 & 3.00 & 1.4013 & .67214 & .452 \\
\hline Fair Coverage of TV on minorities issues & 456 & 1.00 & 3.00 & 2.1184 & .74363 & .553 \\
\hline Worship places of minorities are safe & 456 & 1.00 & 3.00 & 2.0855 & .75253 & .566 \\
\hline Safe worship places of Muslims & 456 & 1.00 & 3.00 & 2.0329 & .71176 & .507 \\
\hline Forceful conversion to Islam & 456 & 1.00 & 3.00 & 2.1711 & .57159 & .327 \\
\hline Forced Marriages in Hindu Community & 456 & 1.00 & 3.00 & 2.1711 & .53587 & .287 \\
\hline Safe business and properties of Minorities & 456 & 1.00 & 3.00 & 2.0066 & .84773 & .719 \\
\hline Interest in detailed story about minorities issues & 456 & 1.00 & 3.00 & 1.5461 & .80251 & .644 \\
\hline Role of TV in the rights of minorities & 456 & 1.00 & 3.00 & 2.1645 & .79097 & .626 \\
\hline TV is articulating rights of minorities objectively & 456 & 1.00 & 3.00 & 2.2303 & .76578 & .586 \\
\hline $\begin{array}{l}\text { TV is articulating the picture of both sides in its } \\
\text { coverage }\end{array}$ & 456 & 1.00 & 3.00 & 2.1645 & .73927 & .547 \\
\hline $\begin{array}{l}\text { TV is creating harmony in Muslims and } \\
\text { minorities }\end{array}$ & 456 & 1.00 & 3.00 & 2.2303 & .74836 & .560 \\
\hline TV is promoting the rights of minorities & 456 & 1.00 & 3.00 & 2.2566 & .70318 & .494 \\
\hline $\begin{array}{l}\text { TV is resolving the conflicts among minorities } \\
\text { and Muslims }\end{array}$ & 456 & 1.00 & 3.00 & 1.5197 & .81984 & .672 \\
\hline Valid N (list wise) & 456 & & & & & \\
\hline
\end{tabular}

\section{T-Test}

\section{Group Statistics}

\begin{tabular}{|l|l|l|l|l|l|}
\hline & Gender & $\mathrm{N}$ & Mean & Std. Deviation & $\begin{array}{c}\text { Std. Error } \\
\text { Mean }\end{array}$ \\
\hline Role of TV in the rights of minorities & & & & & .05196 \\
\hline TV is articulating rights of minorities objectively & Male & 246 & 2.1463 & .81499 & .05267 \\
\cline { 2 - 6 } & Female & 210 & 2.1857 & .76326 & .05257 \\
\hline TV is articulating the picture of both sides in its & Male & 246 & 2.1341 & .82455 & .04660 \\
\cline { 2 - 6 } & Female & 210 & 2.3429 & .67531 & .05023 \\
\hline
\end{tabular}


Online Journal of Communication and Media Technologies

Volume: 7 - Issue: 2 April - 2017

\begin{tabular}{|l|l|l|l|l|l|}
\hline coverage & Female & 210 & 2.2857 & .65934 & .04550 \\
\hline \multirow{2}{*}{ TV is creating harmony in Muslims and minorities } & Male & 246 & 2.1707 & .79496 & .05068 \\
\cline { 2 - 6 } & Female & 210 & 2.3000 & .68511 & .04728 \\
\hline \multirow{2}{*}{ TV is promoting the rights of minorities } & Male & 246 & 2.1951 & .75764 & .04831 \\
\cline { 2 - 6 } & Female & 210 & 2.3286 & .62763 & .04331 \\
\hline \multirow{2}{*}{$\begin{array}{l}\text { TV is resolving the conflicts among minorities and } \\
\text { Muslims }\end{array}$} & Male & 246 & 1.5000 & .81691 & .05208 \\
\cline { 2 - 6 } & Female & 210 & 1.5429 & .82460 & .05690 \\
\hline
\end{tabular}

\begin{tabular}{|c|c|c|c|c|c|c|c|c|c|c|}
\hline \multicolumn{11}{|c|}{ Independent Samples Test } \\
\hline & & \multicolumn{2}{|c|}{$\begin{array}{l}\text { Levene's Test } \\
\text { for Equality of } \\
\text { Variances }\end{array}$} & \multicolumn{7}{|c|}{ t-test for Equality of Means } \\
\hline & & \multirow[t]{2}{*}{$\mathrm{F}$} & \multirow[t]{2}{*}{ Sig. } & \multirow[t]{2}{*}{$\mathrm{t}$} & \multirow[t]{2}{*}{$\mathrm{df}$} & \multirow[t]{2}{*}{$\begin{array}{l}\text { Sig. } \\
(2- \\
\text { tailed) }\end{array}$} & \multirow[t]{2}{*}{$\begin{array}{l}\text { Mean } \\
\text { Difference }\end{array}$} & \multirow[t]{2}{*}{$\begin{array}{l}\text { Std. Error } \\
\text { Difference }\end{array}$} & \multicolumn{2}{|c|}{$\begin{array}{l}95 \% \text { Confidence } \\
\text { Interval of the } \\
\text { Difference }\end{array}$} \\
\hline & & & & & & & & & Lower & Upper \\
\hline \multirow{2}{*}{$\begin{array}{l}\text { Role of TV } \\
\text { in the } \\
\text { rights of } \\
\text { minorities }\end{array}$} & $\begin{array}{l}\text { Equal } \\
\text { variances } \\
\text { assumed }\end{array}$ & 2.276 & .132 & -.529 & 454 & .597 & -.03937 & .07437 & $\begin{array}{l}- \\
.18553\end{array}$ & .10678 \\
\hline & $\begin{array}{l}\text { Equal } \\
\text { variances } \\
\text { not } \\
\text { assumed }\end{array}$ & & & -.532 & 450.097 & .595 & -.03937 & .07399 & $\begin{array}{l}- \\
.18478\end{array}$ & .10603 \\
\hline \multirow{2}{*}{$\begin{array}{l}\mathrm{TV} \text { is } \\
\text { articulating } \\
\text { rights of } \\
\text { minorities } \\
\text { objectively }\end{array}$} & $\begin{array}{l}\text { Equal } \\
\text { variances } \\
\text { assumed }\end{array}$ & 11.925 & .001 & $\begin{array}{l}- \\
2.925\end{array}$ & 454 & .004 & -.20871 & .07136 & $\begin{array}{l}- \\
.34894\end{array}$ & $\begin{array}{l}- \\
.06848\end{array}$ \\
\hline & $\begin{array}{l}\text { Equal } \\
\text { variances } \\
\text { not } \\
\text { assumed }\end{array}$ & & & $\begin{array}{l}- \\
2.971\end{array}$ & 453.245 & .003 & -.20871 & .07025 & $\begin{array}{l}- \\
.34677\end{array}$ & $\begin{array}{l}- \\
.07065\end{array}$ \\
\hline \multirow{2}{*}{$\begin{array}{l}\text { TV is } \\
\text { articulating } \\
\text { the picture } \\
\text { of both } \\
\text { sides in its } \\
\text { coverage }\end{array}$} & $\begin{array}{l}\text { Equal } \\
\text { variances } \\
\text { assumed }\end{array}$ & 3.429 & .065 & $\begin{array}{l}- \\
3.270\end{array}$ & 454 & .001 & -.22474 & .06873 & $\begin{array}{l}- \\
.35980\end{array}$ & $\begin{array}{l}- \\
.08968\end{array}$ \\
\hline & $\begin{array}{l}\text { Equal } \\
\text { variances } \\
\text { not } \\
\text { assumed }\end{array}$ & & & $\begin{array}{l}- \\
3.316\end{array}$ & 453.828 & .001 & -.22474 & .06778 & $\begin{array}{l}- \\
.35793\end{array}$ & $\begin{array}{l}- \\
.09155\end{array}$ \\
\hline \multirow{2}{*}{$\begin{array}{l}\text { TV is } \\
\text { creating } \\
\text { harmony } \\
\text { in Muslims } \\
\text { and } \\
\text { minorities }\end{array}$} & $\begin{array}{l}\text { Equal } \\
\text { variances } \\
\text { assumed }\end{array}$ & 6.484 & .011 & $\begin{array}{l}- \\
1.843\end{array}$ & 454 & .066 & -.12927 & .07013 & $\begin{array}{l}- \\
.26708\end{array}$ & .00854 \\
\hline & $\begin{array}{l}\text { Equal } \\
\text { variances } \\
\text { not } \\
\text { assumed }\end{array}$ & & & $\begin{array}{l}- \\
1.865\end{array}$ & 453.956 & .063 & -.12927 & .06931 & $\begin{array}{l}- \\
.26548\end{array}$ & .00694 \\
\hline $\begin{array}{l}\mathrm{TV} \text { is } \\
\text { promoting }\end{array}$ & $\begin{array}{l}\text { Equal } \\
\text { variances }\end{array}$ & 7.869 & .005 & $\begin{array}{l}- \\
2.027\end{array}$ & 454 & .043 & -.13345 & .06584 & $\begin{array}{l}- \\
.26284\end{array}$ & $\begin{array}{l}- \\
.00406\end{array}$ \\
\hline
\end{tabular}




\begin{tabular}{|c|c|c|c|c|c|c|c|c|c|c|}
\hline \multirow{2}{*}{$\begin{array}{l}\text { the rights } \\
\text { of } \\
\text { minorities }\end{array}$} & assumed & & & & & & & & & \\
\hline & $\begin{array}{l}\text { Equal } \\
\text { variances } \\
\text { not } \\
\text { assumed }\end{array}$ & & & $\begin{array}{l}- \\
2.057\end{array}$ & 453.605 & .040 & -.13345 & .06488 & $\begin{array}{l}- \\
.26095\end{array}$ & $\begin{array}{l}- \\
.00595\end{array}$ \\
\hline \multirow{2}{*}{$\begin{array}{l}\mathrm{TV} \text { is } \\
\text { resolving } \\
\text { the } \\
\text { conflicts } \\
\text { among } \\
\text { minorities } \\
\text { and } \\
\text { Muslims }\end{array}$} & $\begin{array}{l}\text { Equal } \\
\text { variances } \\
\text { assumed }\end{array}$ & .340 & .560 & -.556 & 454 & .578 & -.04286 & .07708 & $\begin{array}{l}- \\
.19434\end{array}$ & .10863 \\
\hline & $\begin{array}{l}\text { Equal } \\
\text { variances } \\
\text { not } \\
\text { assumed }\end{array}$ & & & -.556 & 441.527 & .579 & -.04286 & .07714 & $\begin{array}{l}- \\
.19447\end{array}$ & .10875 \\
\hline
\end{tabular}

\section{Hypothesis}

Pakistani channels have been successful in creating awareness of minorities' issues/rights.

Results of survey support this hypothesis that Pakistani channels have been successful in creating awareness among the public. Results in Table 1 shows that TV industry has been successful making public aware of different minority issues and rights.

Pakistani TV channels are significantly highlighting minority issues through their content.

Statistical data approves this hypothesis that Pakistani TV channels are significantly highlighting the issues of minorities in general masses. Table 1 shows that $M=2.1645$. This suggests that TV is playing its role in highlighting minority rights through their content.

Pakistani channels are significantly promoting minority rights.

Perception of respondents about promotion of minorities rights $\mathrm{M}=2.2566$ support this hypothesis. Mean value (2.2303) of role of TV in creating harmony among Muslims and minorities also support this hypothesis.

Pakistani TV channels are fair in their coverage about minority rights.

Pakistani TV industry is proving unbiased coverage to minority rights in Pakistan. Statistical results of Table 1 depicts that this hypothesis is also approved i.e. $\mathrm{M}=2.2303$ when objective role of TV has been measured. 


\section{Research Questions}

- Are Pakistani TV channels creating awareness about minorities' issues/rights?

Table 1 shows the general understanding about minority issues/rights through TV. Results reveal respondents are aware of different issues of minorities in Pakistan i.e. security issues of worship places $(M=2.0855)$, forced conversion to Islam $(M=2.1711)$, forced marriages $(M=2.1711)$ and lack of security for businesses and properties $(M=2.0066)$. Data shows that TV channels are successful in creating awareness among the general public about the issues/rights of minorities in Pakistan.

- Are Pakistani TV channels highlighting minorities' issues through their content? Mean value (2.1645) of role of TV in highlighting minority rights through their content shows that TV channels are highlighting these issues effectively. An independent t-test was conducted to compare the perception of male and female for role of TV in highlighting minority issues. There is no significant difference in score for male $(\mathrm{M}=2.1463, \mathrm{SD}=.81499)$ and females, $\mathrm{M}=2.1857, \mathrm{SD}=.76326 ; \mathrm{t}(454)=-.529, \mathrm{p}=.597$ (two-tailed) (see table 3)

\section{- Are Pakistani TV channels promoting minorities' rights?}

Table 1 depicts that Pakistani television industry is trying to promote the minority rights in society. For instance, mean value (2.2303) of TV's role in creating harmony between minorities and Muslims shows that it is promoting the issues of minorities. Similarly audience perception about promotion of minorities right in Pakistan through TV (2.2566) give similar picture. Results also reveal that TV has been unsuccessful in resolving the conflict i.e. mean value (1.5197) for this question provide statistical support. An independent t-test was conducted to compare the perception of male and female for promotion of minority issues through TV content. Table 2, 3 shows that there is significant difference in score for males $(\mathrm{M}=2.1951, \mathrm{SD}=.75754)$ and females, $\mathrm{M}=2.3286, \mathrm{SD}=.62763 ; \mathrm{t}(454)=-2.027, \mathrm{p}=$ .043 (two-tailed)

- Do Pakistani channels present an objective view of minorities' issues and concerns?

Table 1 show that Pakistani TV channels are giving an objective analysis of minorities issues in Pakistani society. Results show that TV is playing unbiased role in articulating minorities rights for instance mean value is 2.2303 when respondents gave their perception about objectivity in TV transmission. Likewise, mean value of 2.1645 also represents that TV has been successful in giving both sides of the picture related to minority's issues in Pakistan. An independent t-test was conducted to compare the perception of male and female for creation 
of harmony between minority and Muslims. There is significant difference in score for male $(\mathrm{M}=2.1707, \mathrm{SD}=.79496)$ and females, $\mathrm{M}=2.3000, \mathrm{SD}=.68511 ; \mathrm{t}(454)=-1.843, \mathrm{p}=.066$ (two-tailed)

\section{Discussion}

The qualitative data collected by interviews shows that respondents also recommend the TV channels to highlight the minority right and cover news related to them without any bias.

For instance, one of respondent suggested in the interview that "media should provide a platform for discussion and people must be encouraged to participate in it".

Another respondent proposed that media should inform and educate public about minority rights. "They can do this by broadcasting programs which promote harmony among all segments of the society and help in sustaining the peace". Likewise another account suggests that "TV has the capacity to create the harmony among minorities and Muslims by its programming". Similarly, another respondent said that "media should motivate the government to provide security to minorities and this will help in resolving the conflict between minorities and Muslims". Some respondents recommended the representation of minorities in media houses.

\section{Conclusion}

Respect for minorities is considered a derivation for democratic development of any country. Constitution of Pakistan awards equal rights to all minorities living in the country. Minorities were enjoying good relationship with Muslim community but since few years some blasphemy and violent incidents were reported by media leading to various events all resulting in the death and destruction of the life and property of both communities. Being a forth state of a society, media is expected to represent all marginalized groups within it. Media can play a dual role, not only by giving an account of the different occurrences but also to create harmony among all groups of society regardless of their races, ethnicities and religions. 


\section{References}

Protection of Minority Rights (2005). Retrieved 23 October, 2015, from http://www.colorado.edu/conflict/peace/treatment/minority.htm

Christian colony attack in violation of Islam: Allama Tahir Ashrafi (2013). Retrieved 2nd December, 2015, from http://tribune.com.pk/story/518652/christian-colony-attack-inviolation-of-islam-allama-tahir-ashrafi/

Christian couple killed for 'desecrating Holy Quran' near Lahore: police (2014, 4th November). The Express Tribune

Christian colony attacked in Lahore (2015, May 26). Daily Times,

Demographic Indicators - 1998 Census (2015). Retrieved 20th December, 2015, from http://www.pbs.gov.pk/content/demographic-indicators-1998-census

AFP (2014, 28th March). Blasphemy: Christian sentenced to death in Joseph Colony case.

\section{Dawn}

AFP (2015). Police arrest Christian labourer for blasphemy Retrieved 1st December, 2015, from http://tribune.com.pk/story/951230/pakistan-police-arrest-christian-labourer-forblasphemy/

Ali, Z. (2013). Role of electronic media in changing value system in Pakistan. The International Asian Research Journal, 1(01), 59-65.

Anduiza Perea, E., Jorba, L., \& Gallego Dob $\tilde{A}^{3} n$, A. (2012). Internet use and the political knowledge gap in Spain. Paper presented at the Revisit international sociology.

Chandler, D. (1995). Cultivation Theory Retrieved 2nd October, 2015, from http://www.aber.ac.uk/media/Documents/short/cultiv.html

Commissioner, U. N. H. r. o. o. t. h. (2010). Minority Rights: International Standards and Guidance for Implementation. New York.

Dictionary, O. Minority Retrieved 3rd November, 2015, from http://www.oxforddictionaries.com/definition/english/minority

Dilawr S., S. A., Saleem M., \& Ishfaq H. (2014). Searching for Security: The Rising Marginalization of Religious Communities in Pakistan: Minority Rights Group International.

Emenyeonu, B. (1995). Media uses and gratifications: A review. Africa Media Review, 9(3), 90-113.

Gerbner, G., \& Signorielli, N. (1979). Women and Minorities in Television Drama, 19691978. 
Hagendoorn, A., \& Nekuee, S. (1999). Education and racism: A cross national inventory of positive effects of education on ethnic tolerance: Ashgate Pub Limited.

Henrard, K. (2002). Minority protection in post-apartheid South Africa: Human rights, minority rights, and self-determination: Greenwood Publishing Group.

Imran Gabol, N. H., Waseem Riaz, Ali Akbar, Abbas Haider (2015, 17th March). 15 killed in Taliban attack on Lahore churches. Dawn

Jalil, X. (16 March 2015). Attacks on Christians in Punjab in over a decade. Dawn,

Katz, E., Haas, H., \& Gurevitch, M. (1973). On the use of the mass media for important things. American sociological review, 164-181.

Khan, S. B. (2005). Problems of Women Journalists in Pakistan. Media Asia-Singapore, $35(1), 25$.

Korgaonkar, P. K., \& Wolin, L. D. (1999). A multivariate analysis of web usage. Journal of advertising research, 39, 53-68.

Kozar, A. (2005). The media and cultural rights of ethnic minorities by aida kozar. Paper presented at the Eighth International Seminar Democracy and Human Rights in Multiethnic Societies.

Kymlicka, W. (2002). Multiculturalism and minority rights: West and East. JEMIE, i.

Mastro, D. E., \& Robinson, A. L. (2000). Cops and crooks: Images of minorities on primetime television. Journal of Criminal Justice, 28(5), 385-396.

Middleton, M. (2009). Social Responsibility in the media. Center for International Media Ethics, Oxford University PCMlP. Online. http://www. cimethics. org/en/docs/SR_media. pdf (Accessed August 21, 2010).

Middleton, M. (2009). Social Responsibility in the media. Center for International Media Ethics, Oxford University PCMlP. Online. http://www. cimethics. org/en/docs/SR_media.pdf(Accessed August 21, 2010).

Munir-ul-Anjum, T., Shahnaz (2012). The Role of Christians in the Freedom Movement of Pakistan: An Appraisal. Pakistan Journal of Social Sciences (PJSS), 32(2), 437-443.

News, T. (2015). Seven Muslims among Lahore terror victims Retrieved 2nd December, 2015, from http://www.thenews.com.pk/print/11460-seven-muslims-among-lahoreterror-victims

Ravi, B. (2012). Media and Social Responsibility: A Critical Perspective with Special Reference to Television. Academic research international. 
Roberts, D. F., \& Foehr, U. G. (2008). Trends in media use. The future of children, 18(1), 1137.

Sadruddin, M. M. (2012). Study on the Role of Media, NGOs and Civil Society in Promoting Pluralism in Pakistan. Dialogue, 7(2), 161.

Saleem, S. (2013). Two groups clash in Gujranwala's Christian colony Retrieved 2nd December, 2015, from http://tribune.com.pk/story/530583/christians-muslims-clashin-gujranwala/

Schaefer, R. T. (2004). Racial and ethnic groups (Vol. 1): Prentice Hall.

Shahab, Z. (2010). Muslim-Christian Relations in Pakistan.

Spring, E. R. (2002). Uses \& Gratifications/ Dependency Theory Retrieved 1st December, 2015, from http://zimmer.csufresno.edu/ johnca/spch100/7-4-uses.htm

Stroman, C. A., Merritt, B. D., \& Matabane, P. W. (1989). Twenty years after kernen: The portrayal of African Americans on primeâ€• time television. Howard Journal of Communications, 2(1), 44-56.

Verkuyten, M. (2006). Multicultural recognition and ethnic minority rights: A social identity perspective. European review of social psychology, 17(1), 148-184.

Ward, S. J. (2009). Journalism ethics. The handbook of journalism studies, 295-309.

Watson, I. (1996). The irish language and television: National identity, preservation, restoration and minority rights. British Journal of Sociology, 255-274.

Zahid, L. (2015). Youhanabad Incident Retrieved 1st December 2015, from http://www.pakistantoday.com.pk/2015/03/21/features/youhanabad-incident/ 